\title{
Disseminated pilomyxoid astrocytoma in infancy with novel MUTYH mutation
}

\author{
Yasmin Aghajan, ${ }^{1}$ Michael L Levy, ${ }^{2}$ Robert 0 Newbury, ${ }^{3}$ John Ross Crawford ${ }^{4}$
}

${ }^{1} U C$ San Diego, San Diego, California, USA

${ }^{2}$ Department of Neurosurgery, University of California San Diego, San Diego, California, USA ${ }^{3}$ Department of Pathology, University of California San Diego, San Diego, California, USA

${ }^{4}$ Department of Neurosciences and Pediatrics, University of California San Diego, San Diego, California, USA

\section{Correspondence to} Dr John Ross Crawford, jrcrawford@ucsd.edu

Accepted 14 October 2016

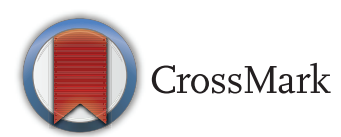

To cite: Aghajan $Y$, Levy ML, Newbury RO, et al. BMJ Case Rep Published online: [please include Day Month Year] doi:10.1136/ bcr-2016-217764

\section{DESCRIPTION}

A 3-month-old girl presented with 5 days of abnormal eye movements. Neurological examination was significant for axial hypotonia. MRI of the brain revealed extensive $\mathrm{T} 2$ prolongation and enhancement within the optic chiasm, optic nerves, bilateral basal ganglia, cerebellum and temporal lobes (figure 1). MRI of the spine showed extensive enhancement along the cervicomedullary junction and cervical and thoracic cord consistent with leptomeningeal metastatic disease (figure 2). The patient underwent right frontotemporal craniotomy for debulking of the tumour and biopsy. Neuropathology revealed a moderately cellular tumour with uniform nuclei, small amounts of myxoid material and perivascular clearing consistent with pilomyxoid astrocytoma (PMA) (figure 3). Molecular analysis demonstrated a novel MUTYH Y165C mutation. The patient died 17 months after diagnosis despite multimodal chemotherapy regimens due to disease progression.

PMA is distinct from pilocytic astrocytoma (PA). PMA demonstrates monomorphous piloid cells in a loose fibrillar and myxoid background, preferentially involves the hypothalamus, and the mean age at diagnosis is 18 months. PMA is more aggressive than PA, with higher rates of cerebrospinal fluid dissemination and shorter progression-free and

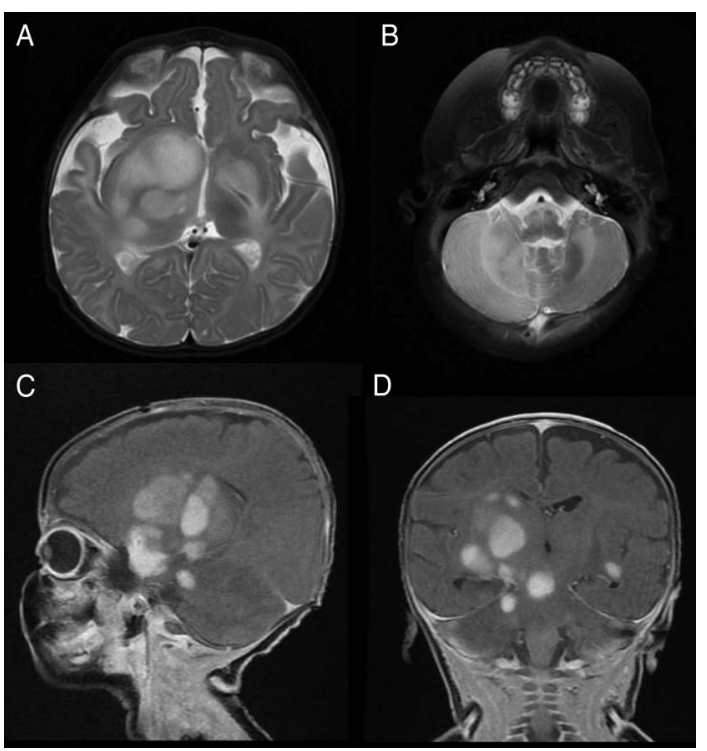

Figure 1 T2-weighted axial (A, B), sagittal (C) and coronal (D) MRI of the brain shows mass-like prolongation and enhancement within the optic chiasm extending to involve the bilateral basal ganglia, temporal lobes and cerebellum.

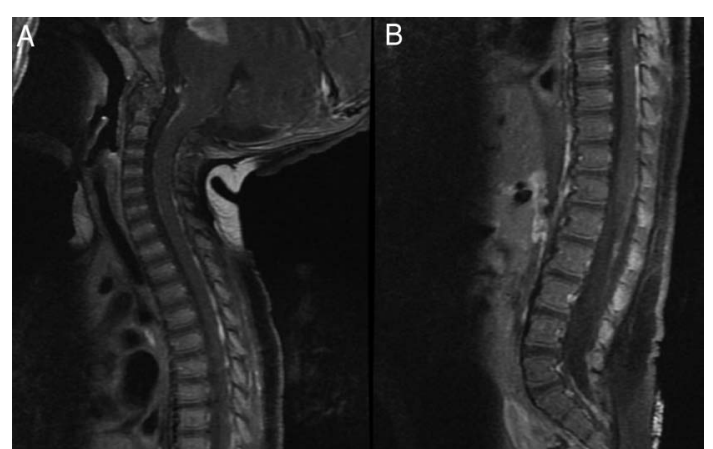

Figure $2 \mathrm{MRI}$ of the spine with contrast demonstrates extensive nodular enhancement along the pial surface of the cervicomedullary junction, cervical cord and thoracic cord consistent with diffuse leptomeningeal metastatic disease.

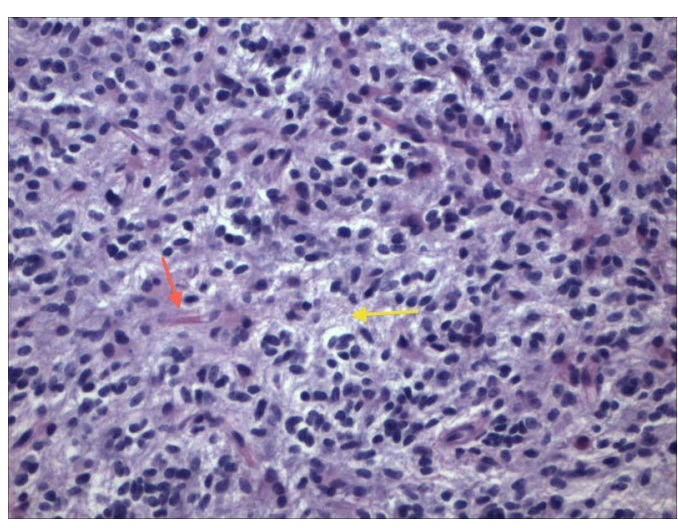

Figure 3 Neuropathology reveals a moderately cellular tumour with uniform nuclei, small amounts of myxoid material in the background (yellow arrow) and perivascular clearing (red arrow) consistent with pilomyxoid astrocytoma $(\times 200)$.

overall survival. There is currently no specific treatment for PMA. ${ }^{1}$

MUTYH is a DNA glycosylase important in base excision repair and thus has tumour-suppressing properties. $^{2}$ MUTYH mutations are traditionally implicated in familial colorectal cancer syndromes and also double the incidence of extraintestinal malignancies, specifically ovarian, bladder and skin cancer. $^{2}$ Recent case reports have described MUTYH mutations in paediatric high-grade gliomas. $^{3}$ Our findings highlight the first reported case of MUTYH mutation in PMA. 


\section{Learning points}

- MUTYH mutations are classically implicated in familial colorectal cancer syndromes and increase the risk of ovarian, bladder and skin cancer but have not yet been shown to increase the risk of primary central nervous system tumours.

- A growing body of the literature suggests that MUTYH may function as a broad tumour suppressor and has been mutated in paediatric high-grade gliomas.

- The molecular genetics of PMA are currently poorly characterised; further studies are necessary to understand the role of MUTYH mutations in the pathogenesis of PMA and other CNS neoplasms.
Twitter Follow Yasmin Aghajan at @yaghajan

Contributors YA, MLL, RON and JRC were all involved in analysis and interpretation of this case. All authors have made substantial contributions and were involved in drafting and revising this work. All authors have reviewed the case report and agree to its content prior to submission.

Competing interests None declared.

Provenance and peer review Not commissioned; externally peer reviewed.

\section{REFERENCES}

1 Komotar RJ, Mocco J, Carson BS, et al. Pilomyxoid astrocytoma: a review. MedGenMed 2004;6:42.

2 Mazzei F, Viel A, Bignami M. Role of MUTYH in human cancer. Mutat Res 2013;743-744:33-43.

3 Kline CN, Joseph NM, Grenert JP, et al. Inactivating MUTYH germline mutations in pediatric patients with high-grade midline gliomas. Neuro-oncology 2016;18:752-3.

Copyright 2016 BMJ Publishing Group. All rights reserved. For permission to reuse any of this content visit http://group.bmj.com/group/rights-licensing/permissions.

BMJ Case Report Fellows may re-use this article for personal use and teaching without any further permission.

Become a Fellow of BMJ Case Reports today and you can:

- Submit as many cases as you like

- Enjoy fast sympathetic peer review and rapid publication of accepted articles

- Access all the published articles

- Re-use any of the published material for personal use and teaching without further permission

For information on Institutional Fellowships contact consortiasales@bmjgroup.com

Visit casereports.bmj.com for more articles like this and to become a Fellow 